\title{
Morphine-Induced Changes in $\delta$ Opioid Receptor Trafficking Are Linked to Somatosensory Processing in the Rat Spinal Cord
}

\author{
Anne Morinville, ${ }^{1,2}$ Catherine M. Cahill, ${ }^{1}$ Haneen Aibak, ${ }^{1}$ Vladimir V. Rymar, ${ }^{1}$ Amynah Pradhan, ${ }^{2}$ Cyrla Hoffert, ${ }^{3}$ \\ Françoise Mennicken, ${ }^{3}$ Thomas Stroh, ${ }^{2}$ Abbas F. Sadikot, ${ }^{1}$ Dajan O'Donnell, ${ }^{3}$ Paul B. S. Clarke, ${ }^{2}$ Brian Collier, ${ }^{2}$ \\ James L. Henry, ${ }_{4}^{4}$ Jean-Pierre Vincent, ${ }^{5}$ and Alain Beaudet ${ }^{1}$ \\ ${ }^{1}$ Montreal Neurological Institute, McGill University, Montreal, Québec, Canada H3A 2B4, ${ }^{2}$ Department of Pharmacology and Therapeutics, McGill \\ University, Montreal, Québec, Canada H3G 1Y6, ${ }^{3}$ Department of Molecular Sciences, AstraZeneca R\&D Montreal, Montreal, Québec, Canada H4S 1Z9, \\ ${ }^{4}$ Department of Physiology and Pharmacology, University of Western Ontario, London, Ontario, Canada N6A 5C1, and 5 Institut de Pharmacologie \\ Moléculaire et Cellulaire, Centre National de la Recherche Scientifique, Université de Nice, 06560 Valbonne, France
}

An in vivo fluorescent deltorphin (Fluo-DLT) internalization assay was used to assess the distribution and regulation of pharmacologically available $\delta$ opioid receptors ( $\delta 0 \mathrm{Rs}$ ) in the rat lumbar (L4-5) spinal cord. Under basal conditions, intrathecal injection of Fluo-DLT resulted in the labeling of numerous $\delta 0 R$-internalizing neurons throughout dorsal and ventral horns. The distribution and number of Fluo-DLT-labeled perikaryal profiles were consistent with that of $\delta 0 \mathrm{R}$-expressing neurons, as revealed by in situ hybridization and immunohistochemistry, suggesting that a large proportion of these cells was responsive to intrathecally administered $\delta 0 \mathrm{R}$ agonists. Pretreatment of rats with morphine for $48 \mathrm{hr}$ resulted in a selective increase in Fluo-DLT-labeled perikaryal profiles within the dorsal horn. These changes were not accompanied by corresponding augmentations in either $\delta 0 \mathrm{R} m R N A$ or ${ }^{125}$ I-deltorphin-II binding levels, suggesting that they were attributable to higher densities of cell surface $\delta 0 \mathrm{R}$ available for internalization rather than to enhanced production of the receptor. Unilateral dorsal rhizotomy also resulted in increased Fluo-DLT internalization in the ipsilateral dorsal horn when compared with the side contralateral to the deafferentation or to non-deafferented controls, suggesting that $\delta 0 \mathrm{R}$ trafficking in dorsal horn neurons may be regulated by afferent inputs. Furthermore, morphine treatment no longer increased Fluo-DLT internalization on either side of the spinal cord after unilateral dorsal rhizotomy, indicating that $\mu \mathrm{OR}$-induced changes in the cell surface availability of $\delta 0 \mathrm{R}$ depend on the integrity of primary afferent inputs. Together, these results suggest that regulation of $\delta 0 \mathrm{R}$ responsiveness through $\mu \mathrm{OR}$ activation in this region is linked to somatosensory information processing.

Key words: opiate; morphine; internalization; fluorescence microscopy; targeting; narcotic; intrathecal; dorsal rhizotomy

\section{Introduction}

Endogenous as well as exogenous opioids exert their effects through interaction with three major opioid receptor (OR) subtypes, referred to as $\mu, \delta$, and $\kappa$, belonging to the G-proteincoupled receptor (GPCR) superfamily (Evans et al., 1992; Kieffer et al., 1992; Chen et al., 1993; Fukuda et al., 1993; Meng et al., 1993; Thompson et al., 1993; Wang et al., 1993; Yasuda et al., 1993). All ORs are implicated in the modulation of pain trans-

\footnotetext{
Received May 29, 2003; revised April 22, 2004; accepted April 26, 2004.

This work was supported by grants from the Canadian Institutes of Health Research and AstraZeneca awarded to A.B. A.M. was funded by fellowships from the Faculty of Medicine and McGill University. C.M.C. was funded by Merck and Company. We extend our gratitude to Naomi Takeda, Mariette Lavallée, Geneviève Guillaume, and Drs. Annabelle Réaux-Le Goazigo and Louis Gendron for technical assistance.

Correspondence should be addressed to Dr. Alain Beaudet, Department of Neurology and Neurosurgery, Montreal Neurological Institute, 3801 University Street, Room 896, Montréal, Québec, Canada H3A 2B4. E-mail: alain.beaudet@mcgill.ca.

A. Morinville's present address: Department of Molecular Sciences, AstraZeneca R\&D Montreal, Montreal, Québec, Canada H4S 1 Z9.

DOI:10.1523/JNEUROSCI.2719-03.2004

Copyright $\odot 2004$ Society for Neuroscience $\quad$ 0270-6474/04/245549-11\$15.00/0
}

mission, but $\mu \mathrm{OR}$-acting agonists are currently preferred for the management of moderate to severe pain. However, the clinical use of $\mu$ opioid drugs is limited by their tendency to cause tolerance and dependence with prolonged or repeated administration and to elicit undesirable effects such as respiratory depression, nausea, and constipation (for review, see Colpaert, 1996; Kreek, 1996). In contrast, $\delta$ OR-acting drugs reportedly produce fewer undesirable effects than $\mu \mathrm{OR}$-acting ones and thereby offer an attractive alternative for pain relief.

Solid anatomical evidence supports a role for $\delta \mathrm{OR}$ in the regulation of spinal nociceptive pathways. Indeed, ligand binding (Fields et al., 1980; Zajac et al., 1989; Besse et al., 1990, 1992a,b,c; Stevens and Seybold, 1995; Mennicken et al., 2003), in situ hybridization (Mansour et al., 1994a; Ji et al., 1995; Minami et al., 1995; Wang and Wessendorf, 2001; Mennicken et al., 2003), and immunohistochemical (Dado et al., 1993; Zhang et al., 1998; Abbadie et al., 2002) data concur in demonstrating the presence of $\delta \mathrm{OR}$ in dorsal root ganglia and primary afferent terminals in the dorsal horn of mammalian spinal cord. Furthermore, an important population of intrinsic dorsal and ventral horn neurons has 

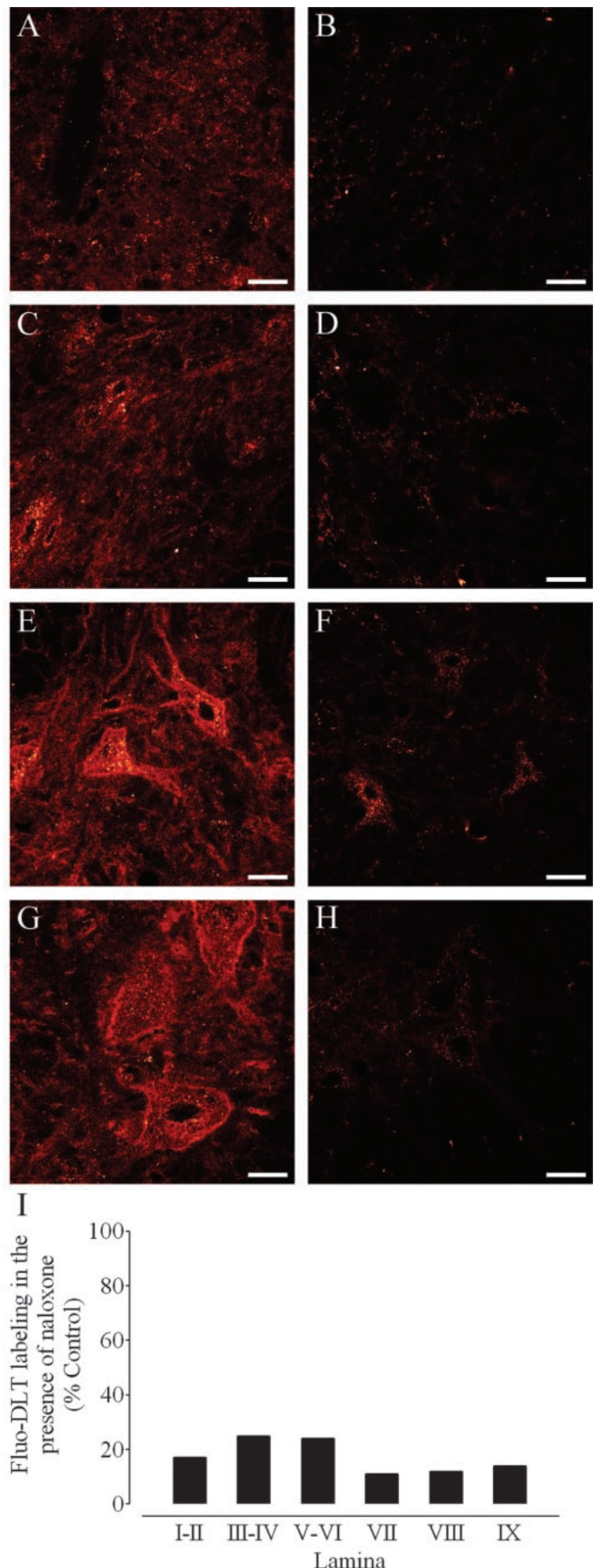

Figure 1. Antagonism of Fluo-DLT labeling by naloxone in the dorsal and ventral horn of the rat spinal cord. $A-H$, A non-pretreated rat (control; $A, C, E, G$ ) and a rat pretreated with naloxone $(B, D, F, H)$ were injected intrathecally with $0.8 \mathrm{nmol}$ of Fluo-DLT. Internalized Fluo-DLT is observed by confocal microscopy in dorsal and ventral horn neurons of the lumbar (L4 -5) spinal been documented to express (Mansour et al., 1994a; Maekawa et al., 1996; Wang and Wessendorf, 2001; Cahill et al., 2001a, 2003; Mennicken et al., 2003) and synthesize (Dado et al., 1993; Arvidsson et al., 1995; Zhang et al., 1998; Mailly et al., 1999; Robertson et al., 1999; Cahill et al., 2001a) $\delta$ OR in both nonhuman primate and rodent spinal cord. Surprisingly, only a small proportion of $\delta \mathrm{ORs}$ is present on the surface of neurons under basal conditions (Cheng et al., 1995, 1997; Elde et al., 1995; Zhang et al., 1998; Cahill et al., 2001a). However, a number of experimental paradigms, including chronic pain, cell depolarization, or specific drug treatments (Cahill et al., 2001b, 2003; Petaja-Repo et al., 2002; Bao et al., 2003; Morinville et al., 2003), can increase targeting of $\delta \mathrm{OR}$ to the plasma membrane.

We recently showed that prolonged pretreatment of rats with $\mu \mathrm{OR}$ agonists promotes the recruitment of $\delta \mathrm{OR}$ to neuronal plasma membranes in the dorsal horn of the lumbar spinal cord, an effect associated with increased effectiveness of intrathecally injected $\delta \mathrm{OR}$ agonists (Cahill et al., 2001b; Morinville et al., 2003). However, the mechanisms that underlie this increased $\delta \mathrm{OR}$ targeting have not been elucidated fully at the systems level. Therefore, a first aim of this study was to determine whether all neurons that express $\delta$ ORs in the gray matter of the lumbar spinal cord are affected by $\mu \mathrm{OR}$ agonist pretreatment.

A number of studies has demonstrated that an important proportion of spinal $\mu \mathrm{ORs}$ are associated with primary afferent terminals arborizing in laminas I-II (Fields et al., 1980; Zajac et al., 1989; Besse et al., 1990, 1992a,b,c; Gouardères et al., 1991; Stevens and Seybold, 1995; Ding et al., 1996; Abbadie et al., 2002). Thus, a second aim of this study was to determine whether the upregulation of cell surface $\delta$ ORs produced by prolonged treatment with $\mu \mathrm{OR}$ agonists could still be elicited in rats lacking afferent primary inputs.

To address these questions, an assessment of the cell surface availability of $\delta$ ORs had to be made over the entire gray matter of the lumbar spinal cord. Traditional receptor visualization techniques are restrictive in their sampling extent (e.g., electron microscopic immunocytochemistry), their ability to discriminate between pharmacologically available and intracellular reserve receptors (e.g., receptor autoradiography or immunohistochemistry), or their cellular resolution (e.g., binding of a nonhydrolysable analog of GTP). Therefore, we developed an assay on the basis of the property of surface-bound peptide agonists to undergo receptor-mediated endocytosis (Ferguson, 2001; Pierce and Lefkowitz, 2001), whereby the cell surface availability of $\delta$ ORs was indirectly assessed through measurement of the internalization of an in vivo-administered fluorescent $\delta \mathrm{OR}$ agonist.

\section{Materials and Methods}

Animals. Experiments were performed in adult male Sprague Dawley rats (200-250 gm; Charles River, Québec, Canada) housed in groups of two per cage. Rats were maintained on a $12 \mathrm{hr}$ light/dark cycle and were allowed free access to food and water. Studies were conducted during the

cord; typical images from laminas I-II $(A, B)$, III-IV $(C, D)$, VIII $(E, F)$, and IX $(G, H)$ are presented. Identical acquisition parameters were used to obtain the images for cells labeled in the presence or absence of naloxone. Images are displayed in glow-scale, where white represents the highest fluorescence intensity and red represents the lowest (black indicates the absence of fluorescent signal). Scale bar, $20 \mu \mathrm{m}$. I, Fluorescence labeling levels for Fluo-DLT intrathecally injected untreated (control) and naloxone-treated rats were determined as described in Materials and Methods. Each bar corresponds to the average fluorescence labeling levels of the naloxonetreated rat divided by the Fluo-DLT-labeling levels of the untreated rat calculated within each specified lamina (3 sections/animal) in one representative experiment. 
light phase of the cycle. Experiments were approved by the animal care committee at McGill University and complied with the policies and directives of the Canadian Council on Animal Care. Control or nonmorphine-pretreated animals refer to either untreated or salinepretreated rats $(0.9 \% \mathrm{NaCl}$ subcutaneously; every $12 \mathrm{hr}$, four injections; experiments were performed $12 \mathrm{hr}$ after the last injection). Morphine pretreatment for $48 \mathrm{hr}$ refers to animals that were treated with increasing doses of morphine sulfate (MS; 5, 8, 10, and $15 \mathrm{mg} / \mathrm{kg}$ subcutaneously) every $12 \mathrm{hr}$; experiments took place $12 \mathrm{hr}$ after the last injection.

In vivo $\delta O R$ internalization assay. Internalized fluorescent $\delta \mathrm{OR}$ agonist, $\omega$-Bodipy 576/589 deltorphin-I 5-aminopentylamide (Fluo-DLT) prepared as described previously (Gaudriault et al., 1997), was visualized in the rat lumbar (L4-5) spinal cord using confocal microscopy. For this purpose, rats were anesthetized with sodium pentobarbital (intraperitoneal administration, $7.7 \mathrm{mg} / 100 \mathrm{gm}$ ) and injected intrathecally via a lumbar puncture with $0.8 \mathrm{nmol}$ Fluo-DLT diluted in $30 \mu \mathrm{l}$ of saline at the L5-6 intervertebral space. For specificity controls, rats were injected both subcutaneously and intrathecally with $1.6 \mu \mathrm{mol}$ of nonfluorescent

A

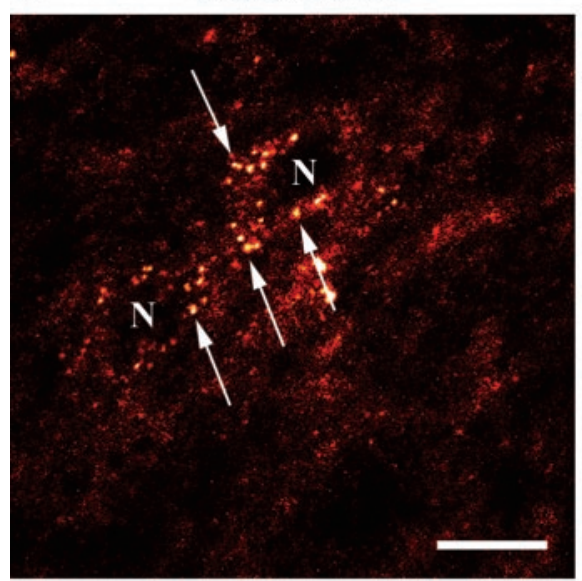

B

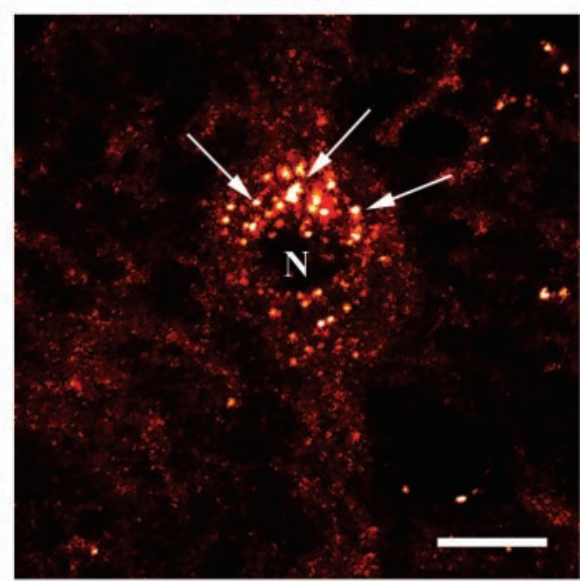

Figure 2. High-magnification confocal microscopic images of Fluo-DLT-labeled neurons in dorsal and ventral horns of the rat spinal cord. Fluorescent puncta (denoted by arrows), corresponding to internalized Fluo-DLT, are evident throughout the perikaryal cytoplasm, sparing the nucleus (N). Images are displayed in glow-scale, where white represents the highest fluorescence intensity and red represents the lowest (black indicates the absence of fluorescent signal). Scale bar, $10 \mu \mathrm{m}$.
A

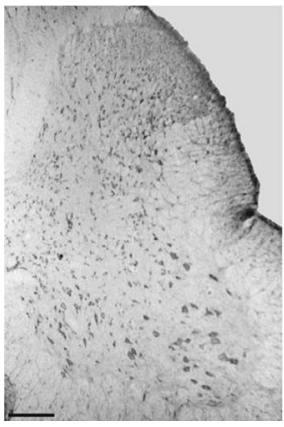

$\mathrm{B}$

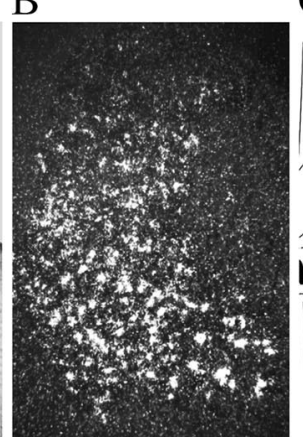

$\mathrm{C}$

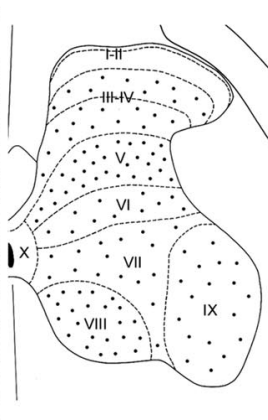

D

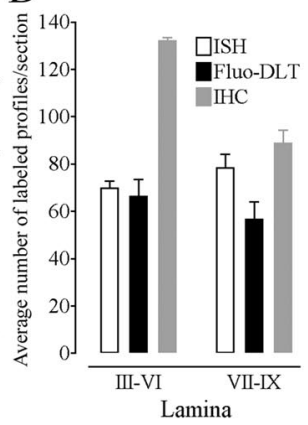

Figure 3. Comparison of the localization of cells labeled for $\delta 0 \mathrm{R}$ in the rat lumbar ( $L 4-5)$ spinal cord. $A, B$, Immunohistochemical labeling of $\delta 0 R$ (Fig. $5 A$ ) [Cahill et al. (2001a), reprinted with permission] ( $A$ ) and $\delta 0 R$ mRNA expression ( $B$ ), as revealed by in situ hybridization, concur in demonstrating the presence of this receptor in neurons distributed throughout the gray matter of the spinal cord. C, Schematic representation of the distribution of Fluo-DLT-labeled perikaryal profiles in the lumbar spinal cord (L5) (Paxinos and Watson, 1986) of control, non-pretreated rats. The number of filled circles within each lamina represents the average number of Fluo-DLT-labeled cell body profiles per section. D, Comparison of the estimated number of cross-sectioned neurons counted by the three techniques in the dorsal (laminas III-VI) and ventral (VII-IX) horns. Fluo-DLT, immunuhistochemical (IHC)- and in situ hybridization (ISH)-labeled profiles were counted as described in Materials and Methods. Because these three techniques used sections of different thickness, counts were corrected to $20 \mu \mathrm{m}$ according to the following formula: [(counts $\times$ 20)/(section thickness in micrometers)]. naloxone 15 min before intrathecal administration of Fluo-DLT. Rats were killed $20 \mathrm{~min}$ after injection of the fluorescent ligand by intra-aortic

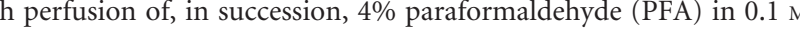
$(100 \mathrm{ml}, \mathrm{pH} 7.4), 20 \%$ sucrose in $0.2 \mathrm{M} \mathrm{PB}(100 \mathrm{ml}, \mathrm{pH} 7.4)$, and $30 \%$ (100 ml, pH 7.4). Lumbar segments of the spinal cord $-80^{\circ} \mathrm{C}$ until sectioning. Frozen tissue was transversely sectioned at the unted onto chrome alum/gelatin-coated slides. equipped with an inverted microscope (oil-immersion objectives, $40 \times$ and $63 \times$ ), an Argon laser with an excitation wavelength of $488 \mathrm{~nm}$ and a tative images were acquired within each lamina for three to five sections en either or both sides of the cord when the two sides were cessed using Zeiss LSM Image browser version 3 and Photoshop version 6.0 (Adobe Systems, San Jose, CA) on an IBM compatible computer.

Perikaryal profiles displaying internalized Fluo-DLT (i.e., intracytoplasmic fluorescent puncta) within each lamina were counted in three to five animals per experimental condition, ensuring that section thickness, number of sections sampled ( $n=10$ per animal), and acquisition parameters were constant between paired experimental groups. Only profiles in which the nucleus could be clearly discerned were counted. In cases where both sides of the cord were identical, cell profiles were counted on both sides and averaged for each section within each lamina. To ensure that differences in the number of labeled perikaryal profiles between experimental groups reflected changes in the number of cells having internalized FluoDLT and not in the size or packing of labeled neurons, the cross-sectional area of Fluo-DLTlabeled profiles was measured in laminas III-V of the dorsal horn using the NIH ScionImage software program (Scion, Frederick, MD) and averaged for each lamina in each animal for both control and morphine-pretreated rats.

Global fluorescence intensity levels over entire confocal microscopic images were quantified by converting the images to a gray scale. Subsequently, using the thresholding function of ScionImage, the Fluo-DLT fluorescence-labeling area above the set threshold was estimated within a standard area; fluorescence-labeling levels within this area were expressed in arbitrary units (AU).

Calculations and statistical analyses were performed using Excel 97 (Microsoft, Seattle, WA), SYSTAT 10.2 (Systat, Richmond, CA), and Prism 3.02 (Graph Pad, San Diego, CA). See figures for specific statistical analysis details.

Neuronal staining. Neuronal phenotype in Fluo-DLT-labeled sections was verified using the Neurotracer Fluorescent Nissl stain according to the instructions of the manufacturer (Molecular Probes, Eugene, OR). Briefly, fluorescently labeled sections were incubated for $30 \mathrm{~min}$ with 0.1 м PBS, pH 7.4, washed twice with 0.1 м PBS, and incubated for $20 \mathrm{~min}$ with Neurotracer diluted 1:50 in $0.1 \mathrm{M}$ PBS. Sections were then rinsed twice with $0.1 \mathrm{M}$ PBS, washed with $0.1 \mathrm{~m}$ PBS for $1 \mathrm{hr}$, mounted with Aquamount, and visualized by confocal microscopy. 


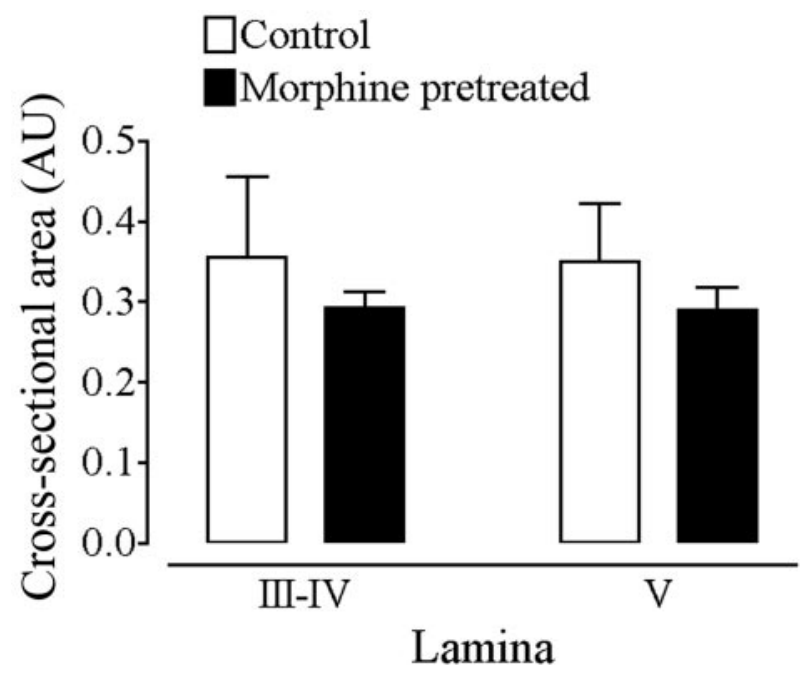

Figure 4. Cross-sectional area of Fluo-DLT-labeled perikaryal profiles in lamina III-V of the rat spinal cord before and after morphine pretreatment. Control and morphine-pretreated rats were injected intrathecally with $0.8 \mathrm{nmol}$ of Fluo-DLT and subsequently processed for confocal microscopic imaging as described in Materials and Methods. Each bar represents the average cross-sectional area of labeled perikaryal profiles in AU for each animal ( $n=3$ animals per condition; 5 sections per animal). No statistically significant difference was noted between morphine-pretreated and control rats in either laminas III-IV or V. Statistical significance was determined by means of a repeated measures two-way ANOVA (drug and lamina as variables).

Light microscopic immunolabeling of rat brain sections. To compare the number of perikaryal profiles displaying internalized Fluo-DLT with that exhibiting $\delta \mathrm{OR}$-immunoreactive proteins, immunopositive perikaryal profiles were counted in sections from the rat spinal cord processed for immunohistochemical detection of $\delta \mathrm{OR}$ in a previous study (Cahill et al., 2001a). In this study, rats were anesthetized with sodium pentobarbitol $(70 \mathrm{mg} / \mathrm{kg}$, intraperitoneal) and perfused through the aortic arch with a freshly prepared solution of $4 \%$ PFA in $0.1 \mathrm{M} \mathrm{PB}(500 \mathrm{ml}, \mathrm{pH} 7.4)$ at $4^{\circ} \mathrm{C}$. Spinal cords were then postfixed in the same fixative solution by immersion for $30 \mathrm{~min}$ followed by overnight cryoprotection in 30\% sucrose in $0.2 \mathrm{M} \mathrm{PB}$, both at $4^{\circ} \mathrm{C}$. After $24 \mathrm{hr}$, tissue was snap-frozen in isopentane at $-45^{\circ} \mathrm{C}$. Immunohistochemistry was performed according to the avidin biotinylated-horseradish-peroxidase complex (ABC) method using a standard $\mathrm{ABC}$ kit (Vector Laboratories, Burlingame, $\mathrm{CA}$ ) and a biotinyltyramide amplification system. Transverse $(30 \mu \mathrm{m})$ sections were cut on a freezing microtome. Free-floating sections were washed with $0.1 \mathrm{M} \mathrm{TBS}$, $\mathrm{pH} 7.4$, followed by preincubation for $1 \mathrm{hr}$ in a blocking solution containing $3 \%$ NGS and $6 \%$ bovine serum albumin (BSA) at room temperature. Serial sections were then incubated at $4^{\circ} \mathrm{C}$ for $48 \mathrm{hr}$ with Quality Controlled Biochemicals (lot number 4430402) or Chemicon (Temecula, CA; lot numbers 17080164, 20010505, 20100177) $\delta$ OR antisera diluted to $0.2-0.5 \mu \mathrm{g} / \mathrm{ml}$ in TBS containing $1 \%$ BSA (TBS-BSA). After rinsing in TBS-BSA (three times for $10 \mathrm{~min}$ each), the sections were incubated at room temperature for $45 \mathrm{~min}$ in biotinylated goat antirabbit IgG (BIO-CAN Scientific, Mississauga, Ontario, Canada) diluted 1:100 in TBS-BSA followed by a 50 min incubation in ABC solution prepared according to the instructions of the manufacturer. Sections were then incubated in a solution of $0.1 \%$ biotinylated tyramide, activated with $0.01 \% \mathrm{H}_{2} \mathrm{O}_{2}$ in TBS-BSA for $10 \mathrm{~min}$, and subsequently subjected to a second 50 min incubation with $A B C$. Visualization of the biotin-bound peroxidase was achieved in some instances by the use of $0.05 \% \mathrm{DAB}, 0.01 \% \mathrm{H}_{2} \mathrm{O}_{2}$, and $0.04 \%$ nickel chloride in $0.1 \mathrm{M}$ Tris buffer, $\mathrm{pH} 7.4$, to produce a black precipitate. Sections were mounted on chrome alum/gelatin-coated slides, air dried, dehydrated with ethanol of increasing concentrations, cleared in xylene, mounted with Permount (Fisher Scientific, Houston, TX), and examined with a Leitz Aristoplan photomicroscope (Leica, Richmond Hill, Ontario, Canada). Perikaryal profiles displaying immunoreactive $\delta \mathrm{OR}$ within each lamina (L4-5) were counted in sections from three animals. Only profiles in which the nucleus could be clearly discerned were counted. Data were expressed as means \pm SEM.

Determination of $\delta O R=R R A$ expression. To investigate the effects of chronic morphine treatment on the expression of $\delta \mathrm{OR}$ mRNA, control $(n=4)$ and morphine-pretreated $(n=4)$ rats were killed by decapitation $12 \mathrm{hr}$ after the last morphine injection. Spinal cords were quickly removed and snap-frozen in isopentane at $-40^{\circ} \mathrm{C}$ for $30 \mathrm{sec}$ and stored at $-80^{\circ} \mathrm{C}$. Frozen tissue was transversely sectioned at $14 \mu \mathrm{m}$ on a cryostat and thaw-mounted onto ProbeOn Plus slides (Fisher Scientific). Slides were stored at $-80^{\circ} \mathrm{C}$ until additional use.

The $\delta \mathrm{OR}$ sense and antisense probes were transcribed in vitro using Uridine $5^{\prime}-\left[\alpha-{ }^{35} S\right]$ thiotriphosphate and cytidine $5^{\prime}-\left[\alpha-{ }^{35} S\right]$ thiotriphosphate ( $\sim 800 \mathrm{Ci} / \mathrm{mmol}$; Amersham Biosciences, Oakville, Ontario, Canada) and T7 or SP6 RNA polymerase (Amersham Biosciences), respectively, from the full-length human $\delta \mathrm{OR}$ sequence $(1.2 \mathrm{~Kb})$ cloned into pcDNA3 and linearized using XbaI or HindIII restriction enzymes (Promega, Madison, WI; New England Biolabs, Mississauga, Ontario, Canada). After transcription, the DNA template was digested with DNase I (Amersham Biosciences). Riboprobes were subsequently purified using G-50 Sepharose microspin columns (Amersham Biosciences). The probes were then hydrolyzed at $60^{\circ} \mathrm{C}$ for $15 \mathrm{~min}$ in $1 \mathrm{M}$ carbonate buffer $\left[0.4 \mathrm{M} \mathrm{NaHCO}, 0.6 \mathrm{M} \mathrm{Na}_{2} \mathrm{CO}_{3}\right.$ in diethyl pyrocarbonate (DEPC)-treated $\mathrm{H}_{2} \mathrm{O}$, pH 9.8] followed by a combined neutralization and precipitation step on dry ice for $30 \mathrm{~min}$ with ethanol containing $25 \mathrm{~m}$ sodium acetate, $0.15 \%$ acetic acid, $15 \mu \mathrm{g} / \mathrm{ml}$ yeast tRNA, and $0.15 \mathrm{~m}$ ammonium acetate. After centrifugation, the pellets were air-dried and resuspended in DEPC-treated $\mathrm{H}_{2} \mathrm{O}$ containing $20 \mathrm{~mm}$ dithiothreitol (Sigma, St. Louis, MO). The quality of labeled riboprobes and their hydrolysis was verified qualitatively by polyacrylamide-urea gel electrophoresis and scintillation counting.

In situ hybridization for $\delta \mathrm{OR}$ was performed as described previously (Cahill et al., 2001a, 2003; Mennicken et al., 2003) on the sections processed as described above using hydrolyzed probes. Although the same pattern of distribution in the CNS has been obtained with hydrolyzed and nonhydrolyzed mRNA $\delta \mathrm{OR}$ probes on adjacent sections, a stronger signal was obtained with the hydrolyzed probe, suggesting a better penetration of this probe compared with the nonhydrolyzed probe. Briefly, sections were fixed with $4 \%$ PFA, rinsed three times in $2 \times$ standard sodium citrate buffer (SSC), equilibrated in $0.1 \mathrm{~m}$ triethanolamine, and treated with $0.25 \%$ acetic anhydride in $0.1 \mathrm{~m}$ triethanolamine. After a rinse in $2 \times$ SSC and dehydration through an ethanol series (50-100\%), hybridization was performed in a buffer containing $75 \%$ formamide (Sigma), $600 \mathrm{~mm} \mathrm{NaCl}, 10 \mathrm{~mm}$ Tris $\mathrm{HCl}$, pH 7.5, 1 mм EDTA, $1 \times$ Denhardt's solution (Sigma), $50 \mu \mathrm{g} / \mathrm{ml}$ denatured salmon sperm DNA (Sigma), 10\% dextran sulfate (Sigma), $20 \mathrm{~mm}$ dithiothreitol, and $\left[{ }^{35} \mathrm{~S}\right]$ labeled cRNA probe $\left(20 \times 10^{6} \mathrm{cpm} / \mathrm{ml}\right)$ at $55^{\circ} \mathrm{C}$ for $18 \mathrm{hr}$ in chambers humidified with $75 \%$ formamide. After hybridization, slides were rinsed in $2 \times$ SSC at room temperature, treated with $20 \mu \mathrm{g} / \mathrm{ml}$ RNase IA in RNase buffer ( $25 \mathrm{~mm} \mathrm{NaCl}, 5 \mathrm{~mm}$ Tris $\mathrm{HCl}$, pH 7.5, 0.5 mm EDTA) for 45 min at $37^{\circ} \mathrm{C}$, and washed to a final stringency of $0.1 \times$ SSC at $70^{\circ} \mathrm{C}$. Sections were then dehydrated, and slides were dipped in Kodak (Rochester, NY) NTB2 emulsion diluted to 1:1 with distilled water and exposed for $8-10$ weeks at $4^{\circ} \mathrm{C}$ before being developed with Kodak D-19 developer. Slides were then counterstained with toluidine blue and viewed on a Leitz Aristoplan photomicroscope (Leica).

Densitometric quantification of mRNA expression was determined on lumbar segment $4-5$ of morphine-pretreated and control animals using a Biocom computer-assisted image analysis system (Historag, Les Ulis, France). Silver grains were counted in four to eight selected regions throughout laminas I-II, III-V, VIII, and IX for at least three spinal cord sections per animal. The total number of grains in each of the selected regions was averaged to give a total grain count per laminar region (i.e., I-II or III-V) for each section of a given animal; laminar counts for each section were averaged in turn to yield values for each animal. The grain counting and region selection was performed by an experimenter who was not aware of the treatment. Statistical details are provided in the figures. In addition, the number of cell bodies labeled by in situ hybridization was counted in six $14 \mu \mathrm{m}$ sections selected at random from four control rats. Data are presented as means \pm SEM.

Autoradiographic detection of $\left[{ }^{125} I\right]$-deltorphin-II binding sites. Serial 
A

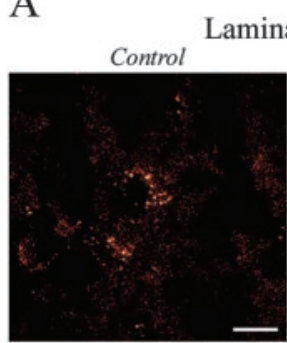

C

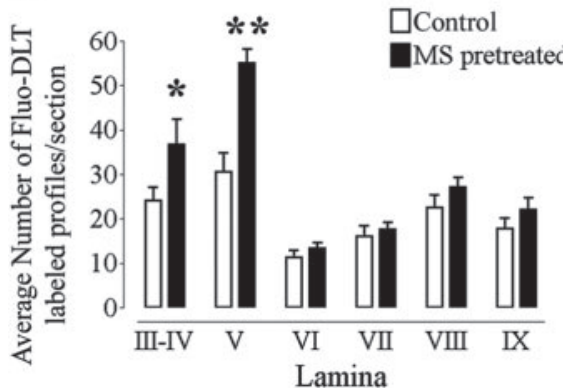

B

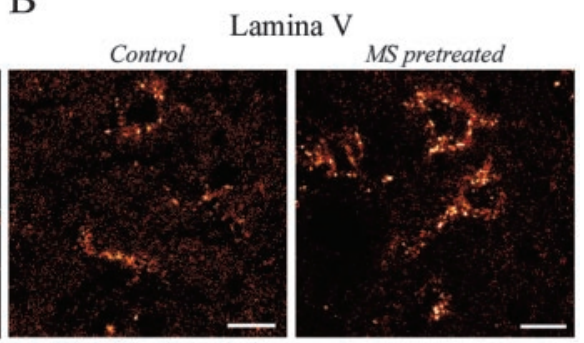

D

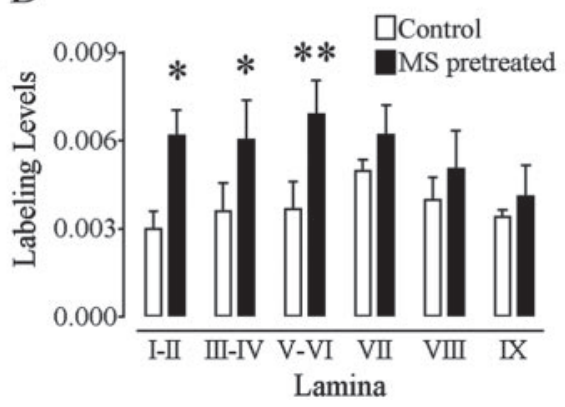

thaw-mounted onto ProbeOn Plus slides or chrome alum/gelatin-coated slides. Slides were stored at $-80^{\circ} \mathrm{C}$ until additional use. Agoniststimulated GTP $\gamma \mathrm{S}$ (a nonhydrolysable analog of GTP) binding was assessed using a procedure adapted from Hyytia et al. (1999). Briefly, sections were thawed to room temperature and rehydrated for $20 \mathrm{~min}$ in assay buffer containing $50 \mathrm{~mm}$ Tris $\mathrm{HCl}, 5 \mathrm{~mm} \mathrm{MgCl}_{2}, 100 \mathrm{~mm} \mathrm{NaCl}$, and $1 \mathrm{~mm}$ EDTA, pH 7.4. Slides were then preincubated for $1 \mathrm{hr}$ with assay buffer plus $2 \mathrm{~mm}$ GDP (Sigma) and $1 \mu \mathrm{M}$ 8-Cyclopentyl-1,3dipropylxanthine (DPCPX; Sigma). The slides were then incubated for $1.5 \mathrm{hr}$ with assay buffer plus $2 \mathrm{~mm}$ GDP, $1 \mu \mathrm{M}$ DPCPX, 1 mм DTT, 225 pM guanosine $5^{\prime}\left(\gamma^{-35} \mathrm{~S}\right.$-thio $)$ triphosphate $\left(\left[{ }^{35} \mathrm{~S}\right] \mathrm{GTP} \gamma \mathrm{S} ; 1250 \mathrm{Ci} / \mathrm{mmol}\right.$; PerkinElmer Life Sciences, Woodbridge, Ontario, Canada), and $0.03-10 \mu \mathrm{M}$ of the selective $\delta \mathrm{OR}$ agonist $\left[\mathrm{D}-\mathrm{Ala}^{2}\right]$-deltorphin II (DLT; Sigma). Binding of $\left[{ }^{35} \mathrm{~S}\right] \mathrm{GTP} \gamma \mathrm{S}$ in the absence of DLT (basal binding) was determined for each rat. Binding of $\left[{ }^{35} \mathrm{~S}\right] \mathrm{GTP} \gamma \mathrm{S}$ in the absence of DLT and in the presence of $10 \mu \mathrm{M}$ unlabeled GTP $\gamma S$ was also determined for each rat (nonspecific binding). Sections were rinsed in ice-cold buffer containing $50 \mathrm{~mm}$ Tris $\mathrm{HCl}$ and $5 \mathrm{~mm} \mathrm{MgCl}_{2}$ (pH 7.4, twice for $5 \mathrm{~min}$ ) followed by distilled deionized water $(2 \mathrm{sec})$. They were then blow-dried thoroughly and exposed to Kodak BioMax MR film overnight.

Signal intensity of the autoradiograms was measured in the left and right gray matter of the lumbar L4-5 segment of the rat spinal cord using the MCID imaging analysis system for both control and morphine-pretreated animals $(n=$ 13-14 rats/group; three to six sections per animal). Two series of ${ }^{14} \mathrm{C}$ standards (American Radiolabeled Chemicals, St. Louis, MO) were used to determine GTP $\gamma \mathrm{S}$ binding levels in femtomoles per milligram. An average in each condition (basal, nonspecific, and DLT 0.03-10

sections adjacent to those used for in situ hybridization were processed for receptor autoradiography using $\left[{ }^{125} \mathrm{I}\right]$-deltorphin-II ([ $\left.{ }^{125} \mathrm{I}\right]$-DLT-II) (Plobeck et al., 2000). The peptide (BACHEM Bioscience, King of Prussia, PA) was iodinated according to the chloramine $\mathrm{T}$ method as described previously (Fraser et al., 1999) (specific activity, $2200 \mathrm{Ci} / \mathrm{mmol}$ ). Sections were preincubated for $30 \mathrm{~min}$ at room temperature in $50 \mathrm{~mm}$ Tris- $\mathrm{HCl}, 120 \mathrm{~mm} \mathrm{NaCl}$, and $1 \mathrm{mM} \mathrm{MgCl}_{2}$ buffer, $\mathrm{pH} 7.4$, and then incubated for $60 \mathrm{~min}$ at room temperature in the same buffer containing 0.5\% BSA, 0.1 mm Bestatin, 0.1 mM PMSF, and 50 pm [ $\left.{ }^{125} \mathrm{I}\right]$-DLT-II. Nonspecific binding was determined in the presence of $1 \mu \mathrm{M}$ naltrindole. Sections were washed three times for $3 \mathrm{~min}$ each in ice-cold Tris- $\mathrm{HCl}$ buffer, air dried, and exposed to Kodak BioMax MS film for 2 weeks.

Signal intensity was measured over individual lamina of both dorsal and ventral horn of the L4-5 segment using the MCID imaging analysis system (Imaging Research, St. Catherines, Ontario, Canada) for both control and morphine-pretreated animals ( $n=4$ rats/group; three to four sections per animal). Film autoradiograms were digitized using the MCID image analysis system equipped with a high resolution Xillix Microimager digital camera (Xillix Technologies, Richmond, BC). Images were processed using Photoshop version 6.0 imaging software (Adobe Systems) on an IBM-compatible computer. Details of the statistical analysis are provided in the figures.

Autoradiographic detection of GTP $\gamma S$ binding. To assess the effect of chronic morphine treatment on $\delta$ OR activation, control $(n=14)$ and morphine-pretreated $(n=13)$ rats were killed by decapitation $12 \mathrm{hr}$ after the last morphine injection as above. Spinal cords were quickly removed and snap-frozen in isopentane at $-40^{\circ} \mathrm{C}$ for $30 \mathrm{sec}$ and stored at $-80^{\circ} \mathrm{C}$. Frozen tissue was transversely sectioned at $14 \mu \mathrm{m}$ on a cryostat and $\mu \mathrm{M})$ in femtomoles per milligram was thereby obtained for each individual animal. The average nonspecific binding level for each animal was subtracted from determinations for that animal. All DLT-induced GTP $\gamma \mathrm{S}$ binding values were then divided by the average basal for each animal (expressed as a percentage). Film autoradiograms were digitized using the MCID image analysis system equipped with a high-resolution digital camera. Images were processed using Photoshop version $6.0 \mathrm{im}$ aging software on an IBM-compatible computer. Statistical calculations were made as described in the figures.

Dorsal rhizotomy. To assess the influence of primary afferent pathways on morphine-induced $\delta \mathrm{OR}$ cell surface recruitment, rats were subjected to a unilateral dorsal rhizotomy before chronic morphine treatment. Rats $(n=6)$ were anesthetized by administration of a mixture of ketamine (60 $\mathrm{mg} / \mathrm{kg}$ ) and xylazine $(6 \mathrm{mg} / \mathrm{kg})$, placed in a holding apparatus, and subjected to a T11 to L3 laminectomy under aseptic conditions. Anesthetic supplements were injected throughout the surgical procedure as needed. Under a dissecting microscope, the dura mater was cut, and dorsal roots corresponding to spinal segments L1 to L5 (or L6) were identified and transected (lidocaine was applied locally to facilitate this process). Care was taken not to damage blood vessels or spinal tissue. After root transection, the exposed spinal cord was covered with saline-moistened Gelfoam, and the area was sutured in two layers (muscle and skin). The antibiotic Tribrissen $(0.013 \mathrm{ml}$ per $100 \mathrm{gm}$ ) was administered once per day, starting $1 \mathrm{~d}$ before the surgery and for $3 \mathrm{~d}$ after surgery; a topical antibiotic (Cicatrin; Glaxo Wellcome, Montreal, Quebec, Canada) was applied over the sutures for $2 \mathrm{~d}$ after the surgery. Postsurgical analgesia 

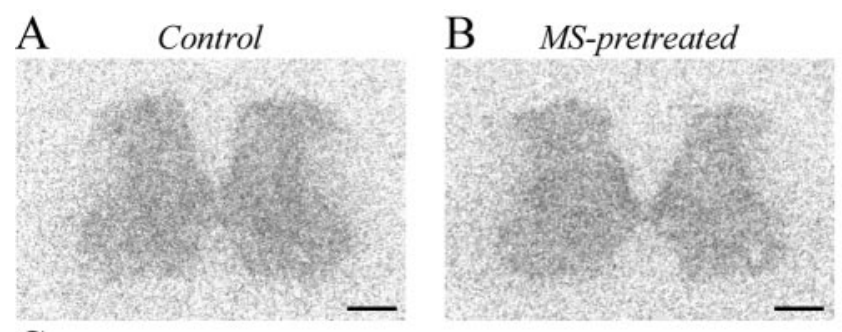

$\mathrm{C}$

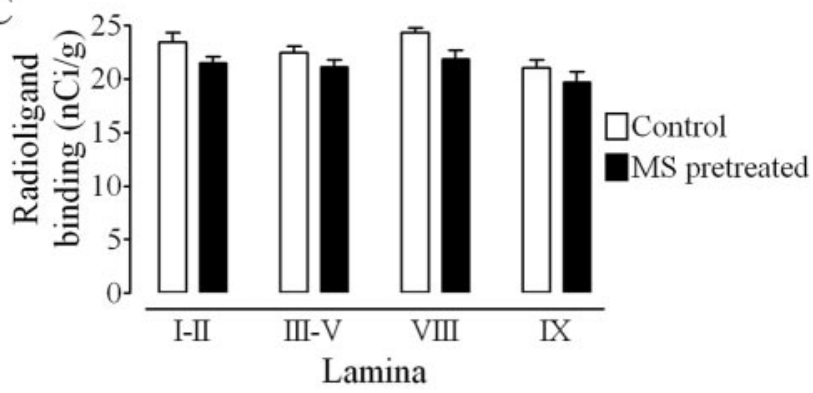

D

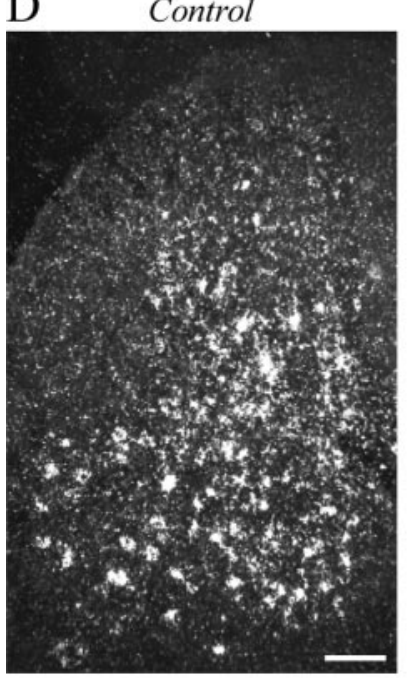

E MS-pretreated

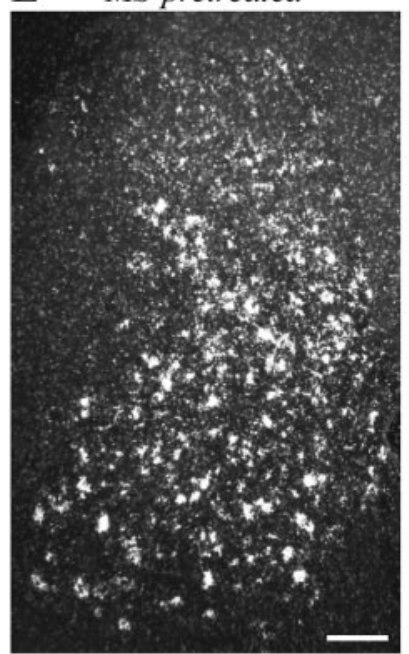

$\mathrm{F}$

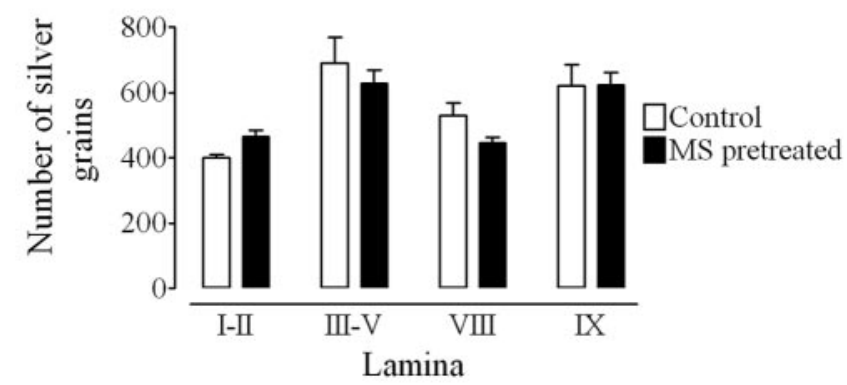

Figure 6. Morphine pretreatment produces no change in $\delta 0 \mathrm{R}$ agonist binding or mRNA expression. $A, B$, Binding of ${ }^{125}$ I-DLT-II in the lumbar (L4-5) spinal cord of control $(A)$ and morphine-pretreated (B) rats. Scale bar, $0.5 \mathrm{~mm}$. C, Densitometric quantification of autoradiographic signal in selected lamina. No significant difference, as assessed by means of a two-way ANOVA followed by a Bonferroni's MCT, was detected between control and morphinepretreated rats in laminas I-II, III-V, VIII, or IX. Radioligand-binding values (nCi/gm) are based on a ${ }^{14} \mathrm{C}$ series of calibration standards. Each bar represents the mean \pm SEM for $n=4$ rats per group. $D, E$, Comparison of $\delta 0 R$ mRNA expression in the lumbar spinal cord of control $(D)$ and morphine-pretreated $(E)$ rats. Scale bar, $0.25 \mathrm{~mm}$. F, Densitometric quantification of silver grains in selected lamina of the lumbar (L4 -5) spinal cord. No significant difference was detected between control and morphine-pretreated rats in laminas I-II, III-V, VIII, or IX (two-way ANOVA followed by a Bonferroni's MCT). Silver grain counts are presented as means \pm SEM for $n=4$ rats per group. was provided by application of topical lidocaine/prilocaine for $1 \mathrm{~d}$ as well as aspirin in Jello for 3-4 d after surgery. After the surgery, individual rats were housed in the presence of a female rat because this practice has been shown to prevent autotomy (Berman and Rodin, 1982).

Surgeries were done in groups of two rats to pair control and morphine-pretreated animals. Saline or morphine injections were initiated $8 \mathrm{~d}$ subsequent to the surgery, at least $48 \mathrm{hr}$ before the in vivo $\delta \mathrm{OR}$ internalization assay. This assay was performed as described above on the tenth day after surgery. The experimenter counting the number of FluoDLT-labeled cells in the spinal cord was not aware of the side of the lesion and the pharmacological treatment.

Primary afferent visualization. To confirm degeneration of primary afferent fibers, reactivity for isolectin $\mathrm{B}_{4}\left(\mathrm{IB}_{4}\right)$ was monitored in sections adjacent to those that were quantified for Fluo-DLT labeling. Sections were washed extensively with $0.1 \mathrm{M}$ PBS before incubation for $1 \mathrm{hr}$ with isolectin GS-IB 4 coupled to Alexa 488 (Molecular Probes) diluted 1:500 in $0.1 \mathrm{M}$ PBS. After several washes with $0.1 \mathrm{M}$ PBS, sections were mounted with Aquamount and visualized by confocal microscopy.

\section{Results}

\section{In vivo internalization of Fluo-DLT}

Intrathecal injection of the highly selective fluorescent $\delta \mathrm{OR}$ agonist, $\omega$-Bodipy red-[D-Ala $\left.{ }^{2}\right]$-deltorphin I resulted in a punctate fluorescent labeling of numerous nerve cell bodies in all layers of the lumbar spinal cord except in laminas I and II (Figs. $1 A, C, E, G, 2 A, B)$. Colocalization of a fluorescent Nissl stain with Fluo-DLT confirmed that these fluorescently labeled cells indeed corresponded to neurons (results not shown). Interestingly, labeled neurons were not confined to the outer portion of the spinal cord but were detected throughout the depth of the gray matter, including lamina $\mathrm{X}$ (see Fig. $3 C$ for schematic representation).

In some cases, Fluo-DLT labeling was seen to extend into proximal dendrites (Fig. 1E). In addition, small individual puncta, presumably contained within cross-sectioned axonal or dendritic processes, were detected throughout the neuropil of the gray matter. This neuropil labeling was particularly dense over laminas I and II (Fig. 1A).

Pretreatment of rats with naloxone before the intrathecal injection of Fluo-DLT almost completely eliminated Fluo-DLT labeling, indicating that the labeling was specific and receptor mediated (Fig. 1B,D,F,H). Densitometric measurements confirmed that $>75 \%$ of the fluorescent signal was abolished in individual laminas of the spinal cord in naloxone-treated animals (Fig. 1I).

The distribution of Fluo-DLT-labeled perikaryal profiles, as schematized from confocal microscopic observations (Fig. $3 C$ ), resembled that of both $\delta \mathrm{OR}$-immunoreactive (Fig. $3 A$ ) and $\delta \mathrm{OR}$ mRNA-expressing (Fig. $3 B$ ) neurons detected in the rat lumbar (L4-5) spinal cord by immunohistochemistry or in situ hybridization, respectively. Comparison of immunohistochemical in situ hybridization and Fluo-DLT labeling data suggest that most $\delta$ OR-expressing neurons in the rat lumbar (L4-5) spinal cord bind and internalize Fluo-DLT in vivo (Fig. 3D).

Effect of morphine pretreatment on Fluo-DLT internalization We demonstrated previously by electron microscopic immunocytochemistry that morphine pretreatment for $48 \mathrm{hr}$ leads to an increase in the density of $\delta \mathrm{OR}$ on the surface of dendrites in the dorsal horn of rodent spinal cord (Cahill et al., 2001b; Morinville et al., 2003). To assess the extent of this upregulation, we used in vivo Fluo-DLT internalization as an indirect assay of cell surface receptor availability.

To quantify the amount of internalized ligand molecules before and after morphine pretreatment, we used two different and 

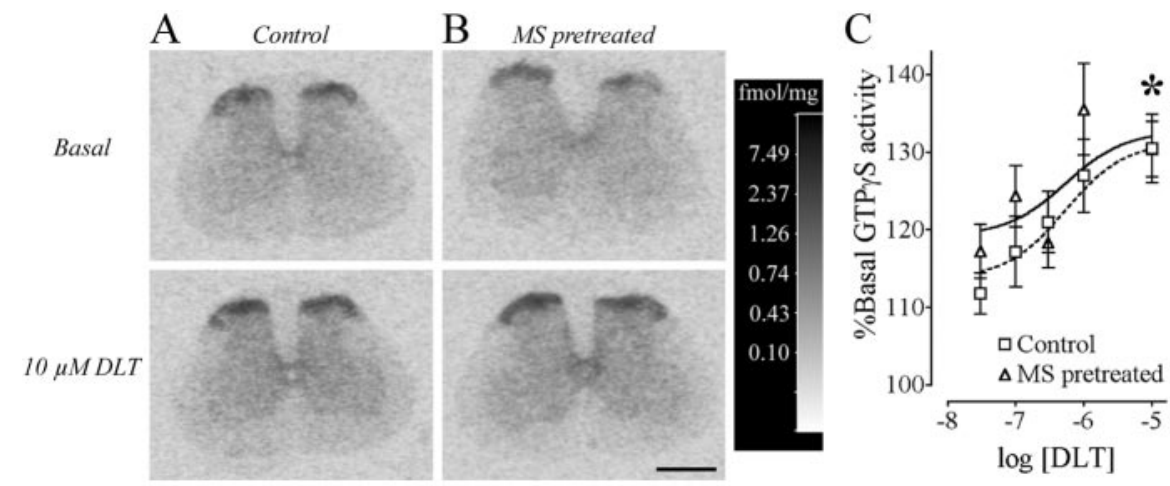

Figure 7. [D-Ala $\left.{ }^{2}\right]$-Deltorphin II-induced GTP $\gamma S$ binding in the lumbar spinal cord. Binding of GT $\gamma S$ in the absence of $\delta 0 R$ agonist (basal) and in the presence of $10 \mu \mathrm{MLLT}$ for control $(n=14 ; A)$ and morphine sulfate (MS)-pretreated $(n=13 ; B)$ rats in a representative experiment from the lumbar $(L 4-5)$ spinal cord is presented. The calibration scale (gray-scale converted to $\mathrm{fmol} / \mathrm{mg}$ using ${ }^{14} \mathrm{C}$ standards) for these four spinal cords taken from the same autoradiographic film is presented. Scale bar, 1.0 $\mathrm{mm}$. C, Densitometric quantification of GTP $\gamma$ S binding in the lumbar spinal cord with increasing doses of deltorphin (expresssed as $\log _{10}$ of the concentration in $\mathrm{mol} / \mathrm{l}$ ) is expressed as a percentage of the basal binding observed in control and MS-pretreated rats. The asterisk denotes statistical significance between the 0.03 and $10 \mu \mathrm{M}$ DLT $(p<0.05)$ for both control and MS-pretreated rats (unpaired $t$ test followed by a Bonferroni's correction), demonstrating a dose-response effect.

complimentary techniques. On one hand, we measured fluorescence intensity levels over individual laminas to provide a global estimate of the labeling over all neuronal elements (cell bodies along with axons and dendrites). On the other hand, we counted the number of Fluo-DLT-labeled perikaryal profiles in each lamina of L4-5 segment. Because nonbiased stereological counting methods were not used, these counts could not be considered absolute. However, they could serve as a basis for comparison between the two treatment groups, provided that morphine treatment did not affect cell size. As seen in Figure 4, administration of morphine under the experimental paradigm used in these studies did not modify the mean cross-sectional area of cells labeled in lamina III-V. This observation suggests that the sizes of Fluo-DLT-labeled cells had likely not been altered by morphine administration.

The distribution pattern of Fluo-DLT-labeled neurons in the lumbar spinal cord was the same in morphine-pretreated as in control rats (Fig. $5 A, B$ ). However, the average number of labeled perikaryal profiles per section was significantly greater in laminas III-IV (Fig. 5C) $(p<0.05)$ and V (Fig. 5C) $(p<0.001)$ in morphine-pretreated rats than in control animals. The average number of Fluo-DLT-labeled profiles counted after morphine pretreatment was comparable with the number of neuronal profiles labeled by immunohistochemistry in the dorsal horn (compare Figs. $3 D$ and $5 C$ ), suggesting that the increased number of labeled profiles detected after morphine pretreatment was attributable to a greater sensitivity in receptor detection within $\delta \mathrm{OR}$ expressing cells than to a greater number of neurons expressing $\delta \mathrm{OR}$. No significant change in the number of Fluo-DLT-positive perikaryal profiles was observed in the ventral horn between morphine-pretreated and control rats (Fig. 5C).

Pretreatment with morphine also resulted in greater overall fluorescence levels throughout the dorsal horn (including laminas I-II) compared with control rats (Fig. 5D). No significant change in overall Fluo-DLT labeling was recorded in the ventral horn between morphine-pretreated and control rats (Fig. 5D).

\section{Effect of morphine pretreatment on $\delta \mathrm{OR}$ binding, in situ hybridization, and $\left[{ }^{35} \mathrm{~S}\right]-\mathrm{GTP} \gamma \mathrm{S}$ binding}

We then sought to determine whether the morphine-induced increase in Fluo-DLT internalization was accompanied by other detectable changes in $\delta \mathrm{OR}$ expression or function. Pretreatment of rats with morphine did not result in any statistically significant change in the density of specific $\left[{ }^{125} \mathrm{I}\right]$-DLT-II binding throughout the gray matter of the lumbar (L4-5) spinal cord when compared with control animals (Fig. 6A-C). Similarly, $\delta$ OR mRNA expression, as evidenced by in situ hybridization, remained unchanged in all layers of the lumbar spinal cord after pretreatment with morphine when compared with control animals (Fig. 6D-F).

In both control and morphinepretreated rats, incubation of spinal cord sections with DLT resulted in a dosedependent increase in $\left[{ }^{35} \mathrm{~S}\right]-\mathrm{GTP} \gamma \mathrm{S}$ binding as detected by autoradiography (Fig. $7 A, B)$. The percentage increase over basal GTP $\gamma \mathrm{S}$ levels was significantly different between the lowest and the highest dose of agonist (Fig. 7C) (unpaired $t$ test; $p<$ 0.05 ). However, no significant difference between morphinepretreated and control rats was detected in the spinal gray matter (Fig. 7C).

\section{Contribution of primary afferent inputs to cell surface availability of $\delta \mathrm{OR}$}

To determine whether the morphine-induced changes in FluoDLT internalization were dependent on the integrity of primary afferent inputs, the effect of chronic morphine pretreatment on the in vivo internalization of Fluo-DLT was then assessed in rhizotomized animals. Before studying the effect of morphine treatment in deafferented spinal cords, we first needed to determine whether rhizotomy itself would produce changes in the amount of internalized Fluo-DLT. Efficiency of the rhizotomy was ascertained histologically using $\mathrm{IB}_{4}$ immunostaining of nonpeptidergic unmyelinated primary afferents. As can be seen in Figure $8, \mathrm{IB}_{4}$ immunoreactivity was completely abolished on the side ipsilateral $\left(A^{\prime}\right)$ when compared with the side contralateral $(A)$ to the transected roots, indicating complete degeneration of primary afferents at the time of experimentation ( $10 \mathrm{~d}$ postlesion).

In rhizotomized rats, intrathecal administration of Fluo-DLT resulted in, as in control nonrhizotomized rats, the labeling of nerve cell bodies throughout the gray matter of the lumbar spinal cord bilaterally (Fig. $8 B, B^{\prime}$ ). However, in contrast to control rats, individual cell bodies in laminas III-IV could no longer be reliably distinguished from background because of an increase in fluorescent puncta over the neuropil (data not shown). Hence, the average number of Fluo-DLT-labeled perikaryal profiles per section was counted only in laminas V-IX. As can be seen in Figure $9 A$, a statistically greater number of labeled perikaryal profiles was detected in lamina V, but not in laminas VI-IX, on the ipsilateral side of the spinal cord in rhizotomized rats when compared with either the contralateral side $(p<0.001)$ or the spinal cord of control rats $(p<0.05)$. In addition, a statistically significant increase in overall fluorescence labeling levels was observed in laminas V-VI of the ipsilateral spinal cord in rhizotomized rats when compared with the contralateral side in the same animals $(p<0.05)$ (Fig. 9B). Fluorescence labeling levels also appeared to be increased on the side ipsilateral to the rhizotomy when compared with nondeafferentated rats; however, statistical comparisons could not be performed because images for these 

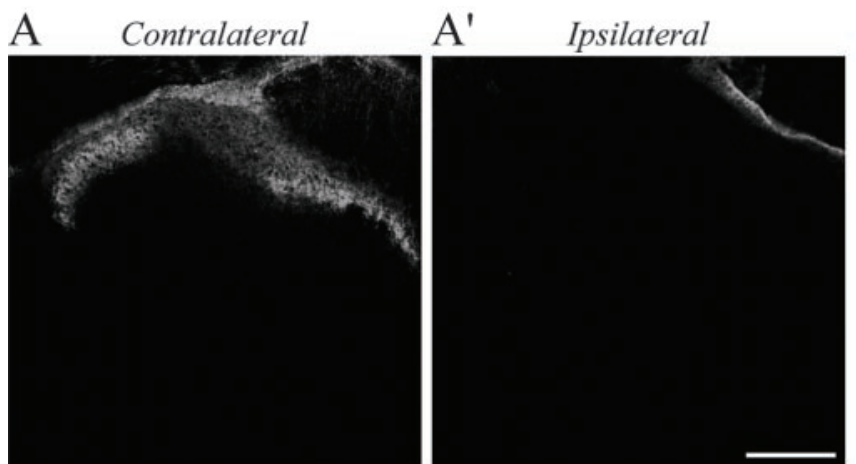

B

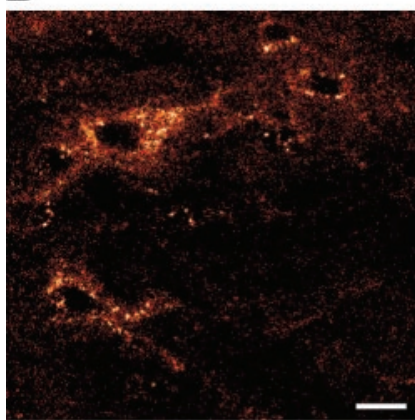

C

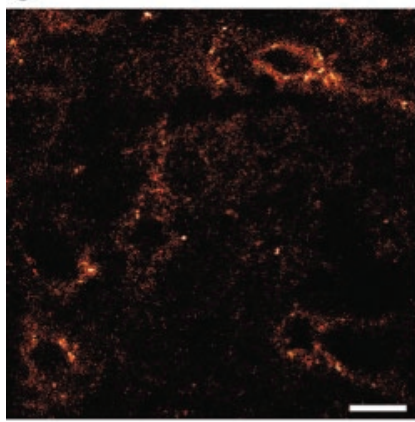

$\mathrm{B}^{\prime}$

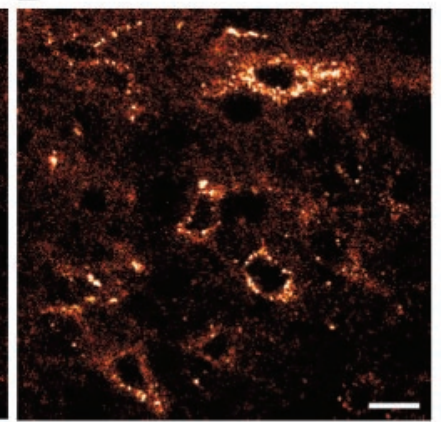

$\mathrm{C}^{\prime}$

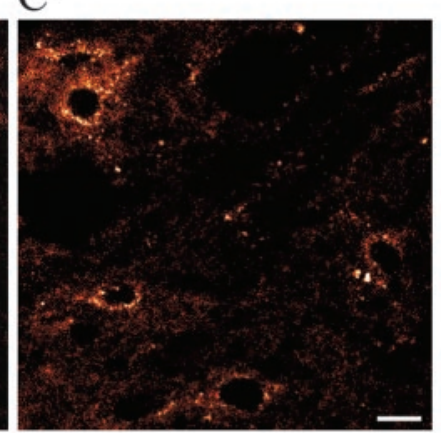

Figure 8. $A-C, \mathbb{I B}_{4}$ immunostaining $\left(A, A^{\prime}\right)$ and Fluo-DLT labeling $\left(B, B^{\prime}, C, C^{\prime}\right)$ in sections from the rat lumbar ( $(4-5)$ spinal cord $10 \mathrm{~d}$ after unilateral dorsal rhizotomy. Selective disappearance of $\mathrm{IB}_{4}$ immunostaining in the superficial layers of the dorsal horn on the side ipsilateral $\left(A^{\prime}\right)$ compared with the side contralateral $(A)$ to the transected roots indicates complete degeneration of nonpeptidergic primary afferent fibers. In nonmorphine-pretreated rats $\left(B, B^{\prime}\right)$, increased internalization of Fluo-DLT is evident in neurons in lamina $V$ on the side ipsilateral $\left(B^{\prime}\right)$ compared with contralateral $(B)$ to the transected roots. In morphine-pretreated animals $\left(C, C^{\prime}\right)$, there is no apparent increase in the intensity of Fluo-DLT neuronal labeling on either the ipsilateral (compare $C^{\prime}$ and $B^{\prime}$ ) and contralateral (compare $C$ and $B$ ) sides. Images $B, B^{\prime}, C$, and $C^{\prime}$ are displayed in red-white glow-scale. Scale bars: $A, A^{\prime}, 200 \mu \mathrm{m} ; B, B^{\prime}, C, C^{\prime}, 10 \mu \mathrm{m}$.

two different sets of experiments were not acquired using identical parameters. In any event, it should be noted that fluorescence labeling levels in the spinal cord after root transection were more variable than those observed between spinal cords of intact animals. Nonetheless, these data suggest that the dorsal rhizotomy itself, independent from any pharmacological treatment, affects the amount of internalized Fluo-DLT and, hence, $\delta$ OR cell surface density in the ipsilateral dorsal horn.

In rhizotomized rats, morphine pretreatment produced no additional increase (over that produced by rhizotomy itself) in the number of Fluo-DLT-labeled perikaryal profiles on the deafferented side of the lumbar spinal cord when compared with the deafferented side of nonmorphine-pretreated rats (Figs. $8 B^{\prime}, C^{\prime}$, $10 A)$. Likewise, overall fluorescence-labeling levels were not significantly different between morphine-pretreated and non- treated rhizotomized rats in all layers of the spinal cord on the side ipsilateral to the lesion (Fig. 10C). Furthermore, morphine pretreatment no longer produced an increase in the average number of Fluo-DLT-labeled cell body profiles (Figs. $8 B, C, 10 B$ ) or Fluo-DLT-labeling levels (Fig. 10D) in the dorsal horn on the side contralateral to the deafferentation. Thus, a unilateral dorsal rhizotomy abolished $\mu \mathrm{OR}$-induced changes in the amount of internalized Fluo-DLT bilaterally in the dorsal horn of the rat spinal cord.

\section{Discussion \\ Methodological considerations}

We previously showed that pretreatment with morphine results in enhanced recruitment of $\delta \mathrm{OR}$ to neuronal plasma membranes and a concomitant increase in $\delta \mathrm{OR}$-mediated antinociception in the spinal cord of rodents (Cahill et al., 2001b; Morinville et al., 2003). In the current study, we sought to determine the location in the spinal cord of neurons that undergo changes in $\delta \mathrm{OR}$ responsiveness in response to morphine pretreatment. To this aim, we developed an assay that indirectly assesses cell surface $\delta \mathrm{OR}$ availability through measurement of the amount of a fluorescent $\delta$ OR agonist (Fluo-DLT) internalized via these receptors over a fixed time period. This assay is based on our previous finding that in neurons in culture, the amount of internalized Fluo-DLT is directly related to the density of cell surface $\delta \mathrm{OR}$ available for internalization, as determined by immunogold electron microscopy (Cahill et al., 2001b). Although this assay does not afford the same degree of precision as immunogold electron microscopy, it lends itself to more extensive tissue sampling over a wider range of animals/treatments.

In the present study, Fluo-DLT was administered in vivo via the intrathecal route. After allowing for the ligand to diffuse in the spinal cord, rats were perfused with paraformaldehyde to wash out cell surface and nonspecifically bound Fluo-DLT molecules and to trap internalized molecules into endosomes. Accordingly, Fluo-DLT-labeling pattern was highly punctate, as expected for ligand concentrated in early endosomes (Gaudriault et al., 1997).

\section{Fluo-DLT internalization under basal conditions}

Intrathecal injection of Fluo-DLT resulted in the labeling of numerous cells in both the dorsal and ventral horn of the rat lumbar (L4-5) spinal cord. These Fluo-DLT-internalizing cells all stained for Neurotracer, in conformity with our previous finding that $>95 \%$ of $\delta$ OR-immunoreactive elements detected in the superficial layers of the rat lumbar spinal cord were neuronal (Cahill et al., 2001a). Fluo-DLT labeling was inhibited by naloxone, an opioid antagonist, in all laminas of the spinal cord, indicating that it was specific and receptor mediated. The labeling of cells throughout the depth of the spinal cord was surprising. Indeed, it is generally assumed that peptides penetrate tissue poorly, and hence one might have expected that only cells at the edge of the gray matter (i.e., the closest to the spinal cord surface and CSF) would have internalized Fluo-DLT. These findings suggest that spinal diffusion of exogenously applied peptides might be greater than heretofore reported.

The distribution and number of Fluo-DLT-labeled perikaryal profiles matched those of $\delta \mathrm{OR}$-expressing cells detected by immunohistochemistry or in situ hybridization at the same segmental level (Cahill et al., 2001a; our study), suggesting that many neurons expressing $\delta \mathrm{ORs}$ had responded to agonist application. In addition to fluorescently labeled neuronal cell bodies, fluorescent puncta were detected throughout the neuropil of the dorsal horn, especially in laminas I-II. These fluorescent puncta could 


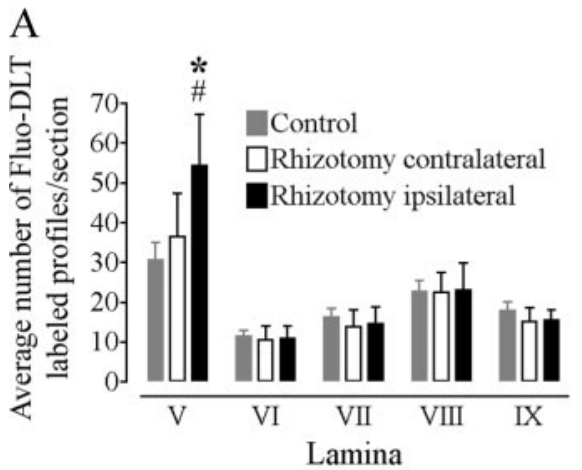

B

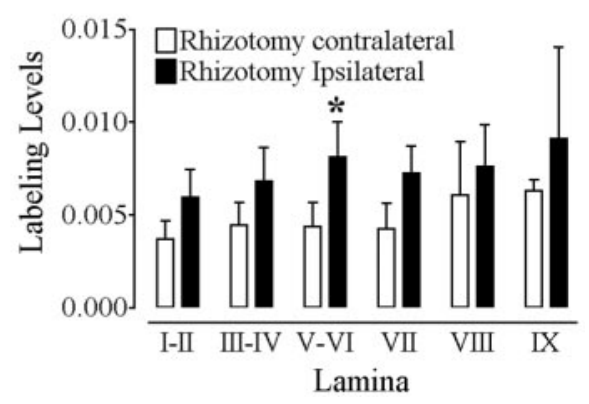

Figure 9. Effect of unilateral dorsal rhizotomy on Fluo-DLT labeling in the rat lumbar spinal cord. $A$, An increase in the number of Fluo-DLT-positive profiles is observed in laminas V-VI of the ipsilateral side of nonmorphine-pretreated rhizotomized rats when compared with either the side contralateral to the lesion (two-way ANOVA; Bonferroni's MCT; $p<0.001$; denoted by \#) or to control nonlesioned (two-way ANOVA; Bonferroni's MCT; $p<0.05$; denoted by *) rats. $B$, Fluorescence labeling levels were significantly greater in nonmorphine-pretreated rhizotomized rats in laminas V-VI of the ipsilateral side compared with the contralateral side of lesioned animals (paired $t$ test; $p<0.05$; denoted by ${ }^{*}$ ), in agreement with the increase in the number of Fluo-DLT-labeled cells.

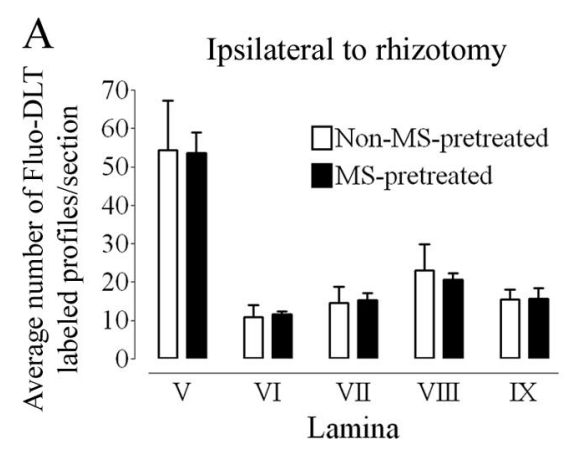

C

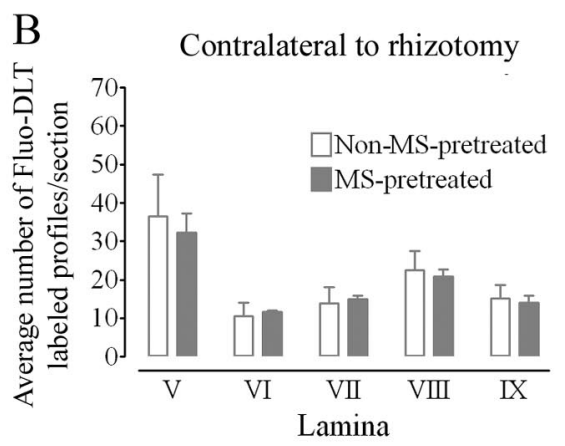

D

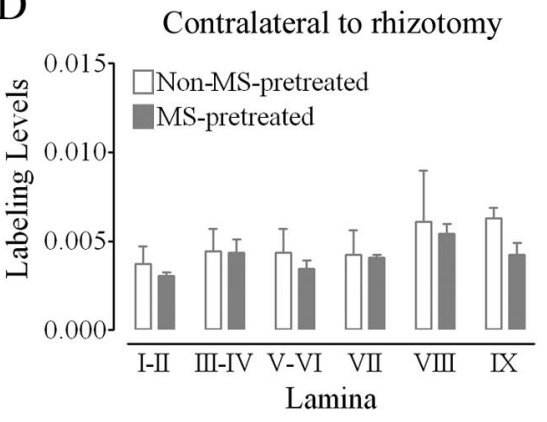

\section{Morphine-induced changes in $\delta O R$ availability}

A major finding of the present study was the robust increase in the amount of internalized Fluo-DLT in the dorsal horn of the spinal cord after morphine pretreatment for $48 \mathrm{hr}$. This increase could have resulted from either enhanced $\delta \mathrm{OR}$ internalization rate or augmented $\delta \mathrm{OR}$ cell surface availability. Because our previous studies demonstrated an increase in $\delta \mathrm{OR}$ cell surface density in the dorsal horn of rodents pretreated with morphine (Cahill et al., 2001b; Morinville et al., 2003) and because this increase in cell surface density was shown to translate into enhanced FluoDLT internalization in vitro (Cahill et al., 2001b), we interpreted the present results to reflect a selective augmentation in $\delta \mathrm{OR}$ cell surface availability rather than an enhancement of $\delta \mathrm{OR}$ internalization rate. Both [ $\left.{ }^{125} \mathrm{I}\right]$-DLT-II binding and $\delta \mathrm{OR}$ mRNA levels in spinal cord sections from morphine-pretreated rats were similar to those observed in sections from control animals, suggesting that the increase in the amount of internalized Fluo-DLT and, hence, in the availability of cell surface $\delta \mathrm{OR}$ was the consequence of a trafficking event and not of an increase in overall $\delta \mathrm{OR}$ receptor levels.

GPCR activation by agonists and coupling to intracellular signaling cascades can be monitored by measuring the binding levels of $\left[{ }^{35} \mathrm{~S}\right]-\mathrm{GTP} \gamma \mathrm{S}$ (for review, see Sim et al., 1997). However, DLT-induced GTP $\gamma S$ binding was not significantly different between morphine-pretreated and control animals. This lack of effect suggests that the autoradiographic detection of DLT-induced $\left[{ }^{35} \mathrm{~S}\right]-\mathrm{GTP} \gamma \mathrm{S}$ binding levels is less sensitive than the present in vivo internalization technique for detecting changes in pharmacologically available cell surface $\delta \mathrm{OR}$.

We originally hypothesized that changes in $\delta$ OR internalization would be observed throughout the spinal cord because localization studies had demonstrated the presence of $\mu \mathrm{OR}$ in all laminas of the rat spinal cord (Goodman et al., 1980; Gouardères et al., 1991, 1993; Stevens et al., correspond to ligand internalized in axon terminals and crosssectioned dendrites. Fluo-DLT labeling of axons would be consistent with the reported association of $\delta \mathrm{OR}$ with primary afferent axons (Fields et al., 1980; Zajac et al., 1989; Besse et al., 1990, 1992a,b,c; Dado et al., 1993; Elde et al., 1995; Stevens et al., 1995; Abbadie et al., 2002; Mennicken et al., 2003) and the demonstration that peptide ligands may be internalized presynaptically (Nguyen et al., 2002). Fluo-DLT labeling of dendrites would concur with the presence, within laminas I and II, of dendritic arborizations of neurons from deeper layers (Willis and Coggeshall, 1991) and the demonstration of Fluo-DLT internalization in dendrites of neurons in culture (Lee et al., 2002).
1991; Hiller et al., 1994; Maekawa et al., 1994; Mansour et al., 1994a,b; Abbadie et al., 2000, 2001). However, the increase in the amount of internalized Fluo-DLT was restricted to the dorsal horn, suggesting that factors more complex than $\mu \mathrm{OR} / \delta \mathrm{OR}$ colocalization are involved in regulating $\delta \mathrm{OR}$ plasma membrane density. In this context, it is important to recall that the dorsal horn is intimately involved in the processing of primary afferent information, including nociception (for review, see Willis and Coggeshall, 1991), and that $\mu$ ORs located on primary afferent terminals in the dorsal horn presynaptically regulate afferent information (Fields et al., 1980; Zajac et al., 1989; Besse et al., 1990, 
1992a,b,c; Gouardères et al., 1991; Mansour et al., 1994a,b; Ding et al., 1995, 1996; Stevens and Seybold, 1995; Abbadie et al., 2002). We therefore hypothesized that $\mu \mathrm{OR}$ agonists acting at the level of incoming afferent fibers might be regulating $\delta \mathrm{OR}$ responsiveness throughout the dorsal horn.

\section{Abolition of primary afferent input}

After unilateral rhizotomy, we observed a significant increase in the amount of internalized Fluo-DLT in lamina V on the deafferented side when compared with the contralateral side, suggesting that $\delta \mathrm{OR}$ availability was enhanced on the lesioned side. In contrast, previous studies have demonstrated dramatic decreases in SOR opioid binding (Fields et al., 1980; Zajac et al., 1989; Besse et al., 1990, 1992a,b,c; Stevens and Seybold, 1995) and immunoreactivity (Dado et al., 1993; Abbadie et al., 2002) in ipsilateral laminas I-II after dorsal rhizotomy, presumably reflecting a loss of presynaptic $\delta \mathrm{OR}$. However, none of these studies reported any increase in deeper laminas (Besse et al., 1990, 1991, 1992a,b,c; Stevens and Seybold, 1995; Abbadie et al., 2002), in keeping with our interpretation that binding and immunohistochemical studies, in contrast to the present in vivo internalization assay, label all receptors and not merely pharmacologically responsive ones. Our results therefore suggest that primary afferent inputs regulate the cell surface density of $\delta \mathrm{OR}$ in intrinsic dorsal horn neurons through mechanisms that may or may not be dependent on the activation of $\mu \mathrm{OR}$. They also suggest that pain resulting from damage or degeneration of primary afferent fibers might be particularly sensitive to treatment with $\delta \mathrm{OR}$ agonists.

Morphine pretreatment of rats with unilateral dorsal rhizotomy did not lead to any additional increase in the amount of Fluo-DLT internalized on the deafferented side. However, the baseline number of Fluo-DLT-labeled perikaryal profiles on the side of the lesion was comparable with the number Fluo-DLTlabeled profiles in morphine-pretreated, nonrhizotomized rats, suggesting that the maximal number of neurons that could be labeled in lamina $\mathrm{V}$ had been attained as a result of rhizotomy itself. Hence, it is unclear whether the lack of morphine effect on the side of the deafferentation was attributable to suppression of presynaptic $\mu \mathrm{ORs}$ or to a pre-existing saturation of $\delta \mathrm{OR}$ upregulatory mechanisms.

However, chronic morphine treatment also failed to increase Fluo-DLT internalization on the side contralateral to the deafferentation. In this case, the lack of morphine effect could not be attributed to saturation of $\delta \mathrm{OR}$ upregulatory mechanisms, because baseline, premorphine treatment levels of Fluo-DLTlabeled cells were the same as in control rats. Therefore, it appears that unilateral dorsal rhizotomy produces changes on the contralateral side such that the cell surface density of $\delta$ ORs can no longer be regulated through chronic stimulation with $\mu \mathrm{OR}$ agonists. Bilateral decreases in $\mu \mathrm{OR}$-binding sites have been reported in the dorsal horn after unilateral rhizotomy (Besse et al., 1992a,b; Stevens and Seybold, 1995), suggesting that the lack of increase in the amount of Fluo-DLT internalized might result from a decrease in $\mu \mathrm{OR}$ available for the expression of morphine effects. However, other more complex mechanisms could also be involved given the extensive contralateral neuroanatomical changes detected after unilateral injuries (for review, see Koltzenburg et al., 1999). In any event, the present results indicate that the $\mu \mathrm{OR}$-induced regulation of $\delta \mathrm{OR}$ responsiveness in the dorsal horn of the spinal cord is dependent on the integrity of primary afferent inputs and may hence be linked to somatosensory processing.

\section{References}

Abbadie C, Pan YX, Pasternak GW (2000) Differential distribution in rat brain of mu opioid receptor carboxy terminal splice variants MOR-1Clike and MOR-1-like immunoreactivity: evidence for region-specific processing. J Comp Neurol 419:244-256.

Abbadie C, Pasternak GW, Aicher SA (2001) Presynaptic localization of the carboxy-terminus epitopes of the mu opioid receptor splice variants MOR-1C and MOR-1D in the superficial laminae of the rat spinal cord. Neuroscience 106:833-842.

Abbadie C, Lombard MC, Besson JM, Trafton JA, Basbaum AI (2002) Mu and delta opioid receptor-like immunoreactivity in the cervical spinal cord of the rat after dorsal rhizotomy or neonatal capsaicin: an analysis of pre- and postsynaptic receptor distributions. Brain Res 930:150-162.

Arvidsson U, Dado RJ, Riedl M, Lee JH, Law PY, Loh HH, Elde R, Wessendorf MW (1995) Delta-opioid receptor immunoreactivity: distribution in brainstem and spinal cord, and relationship to biogenic amines and enkephalin. J Neurosci 15:1215-1235.

Bao L, Jin SX, Zhang C, Wang LH, Xu ZZ, Zhang FX, Wang LC, Ning FS, Cai HJ, Guan JS, Xiao HS, Xu ZQ, He C, Hokfelt T, Zhou Z, Zhang X (2003) Activation of delta opioid receptors induces receptor insertion and neuropeptide secretion. Neuron 37:121-133.

Berman D, Rodin BE (1982) The influence of housing condition on autotomy following dorsal rhizotomy in rats. Pain 13:307-311.

Besse D, Lombard MC, Zajac JM, Roques BP, Besson JM (1990) Pre- and postsynaptic distribution of mu, delta and kappa opioid receptors in the superficial layers of the cervical dorsal horn of the rat spinal cord. Brain Res 521:15-22.

Besse D, Lombard MC, Perrot S, Besson JM (1992a) Regulation of opioid binding sites in the superficial dorsal horn of the rat spinal cord following loose ligation of the sciatic nerve: comparison with sciatic nerve section and lumbar dorsal rhizotomy. Neuroscience 50:921-933.

Besse D, Lombard MC, Besson JM (1992b) Plasticity of mu and delta opioid receptors in the superficial dorsal horn of the adult rat spinal cord following dorsal rhizotomies: a quantitative autoradiographic study. Eur J Neurosci 4:954-965.

Besse D, Lombard MC, Besson JM (1992c) Time-related decreases in mu and delta opioid receptors in the superficial dorsal horn of the rat spinal cord following a large unilateral dorsal rhizotomy. Brain Res 578:115-127.

Cahill CM, McClellan KA, Morinville A, Hoffert C, Hubatsch D, O’Donnell D, Beaudet A (2001a) Immunohistochemical distribution of delta opioid receptors in the rat central nervous system: evidence for somatodendritic labeling and antigen-specific cellular compartmentalization. J Comp Neurol 440:65-84.

Cahill CM, Morinville A, Lee MC, Vincent JP, Collier B, Beaudet A (2001b) Prolonged morphine treatment targets delta opioid receptors to neuronal plasma membranes and enhances delta-mediated antinociception. J Neurosci 21:7598-7607.

Cahill CM, Morinville A, Hoffert C, O’Donnell D, Beaudet A (2003) Upregulation and trafficking of delta opioid receptor in a model of chronic inflammation: implications for pain control. Pain 101:199-208.

Chen Y, Mestek A, Liu J, Hurley JA, Yu L (1993) Molecular cloning and functional expression of a mu-opioid receptor from rat brain. Mol Pharmacol 44:8-12.

Cheng PY, Svingos AL, Wang H, Clarke CL, Jenab S, Beczkowska IW, Inturrisi CE, Pickel VM (1995) Ultrastructural immunolabeling shows prominent presynaptic vesicular localization of delta-opioid receptor within both enkephalin- and nonenkephalin-containing axon terminals in the superficial layers of the rat cervical spinal cord. J Neurosci 15:5976-5988.

Cheng PY, Liu-Chen LY, Pickel VM (1997) Dual ultrastructural immunocytochemical labeling of mu and delta opioid receptors in the superficial layers of the rat cervical spinal cord. Brain Res 778:367-380.

Colpaert FC (1996) System theory of pain and of opiate analgesia: no tolerance to opiates. Pharmacol Rev 48:355-402.

Dado RJ, Law PY, Loh HH, Elde R (1993) Immunofluorescent identification of a delta $(\delta)$-opioid receptor on primary afferent nerve terminals. NeuroReport 5:341-344.

Ding YQ, Nomura S, Kaneko T, Mizuno N (1995) Co-localization of muopioid receptor-like and substance P-like immunoreactivities in axon terminals within the superficial layers of the medullary and spinal dorsal horns of the rat. Neurosci Lett 198:45-48. 
Ding YQ, Kaneko T, Nomura S, Mizuno N (1996) Immunohistochemical localization of mu-opioid receptors in the central nervous system of the rat. J Comp Neurol 367:375-402.

Elde R, Arvidsson U, Riedl M, Vulchanova L, Lee JH, Dado R, Nakano A, Chakrabarti S, Zhang X, Loh HH (1995) Distribution of neuropeptide receptors. New views of peptidergic neurotransmission made possible by antibodies to opioid receptors. Ann NY Acad Sci 757:390-404.

Evans CJ, Keith Jr DE, Morrison H, Magendzo K, Edwards RH (1992) Cloning of a delta opioid receptor by functional expression. Science 258:1952-1955.

Ferguson SS (2001) Evolving concepts in G protein-coupled receptor endocytosis: the role in receptor desensitization and signaling. Pharmacol Rev 53:1-24.

Fields HL, Emson PC, Leigh BK, Gilbert RF, Iversen LL (1980) Multiple opiate receptor sites on primary afferent fibres. Nature 284:351-353.

Fraser GL, Labarre M, Godbout C, Butterworth J, Clarke PB, Payza K, Schmidt R (1999) Characterization of $\left[{ }^{125} \mathrm{I}\right]$ AR-M100613, a highaffinity radioligand for delta opioid receptors. Peptides 20:1327-1335.

Fukuda K, Kato S, Mori K, Nishi M, Takeshima H (1993) Primary structures and expression from cDNAs of rat opioid receptor delta- and musubtypes. FEBS Lett 327:311-314.

Gaudriault G, Nouel D, Dal Farra C, Beaudet A, Vincent JP (1997) Receptor-induced internalization of selective peptidic mu and delta opioid ligands. J Biol Chem 272:2880-2888.

Goodman RR, Snyder SH, Kuhar MJ, Young III WS, (1980) Differentiation of delta and mu opiate receptor localizations by light microscopic autoradiography. Proc Natl Acad Sci USA 77:6239-6243.

Gouardères C, Beaudet A, Zajac JM, Cros J, Quirion R (1991) High resolution radioautographic localization of $\left[{ }^{125} \mathrm{I}\right] \mathrm{FK}-33-824$-labelled mu opioid receptors in the spinal cord of normal and deafferented rats. Neuroscience 43:197-209.

Gouardères C, Tellez S, Tafani JA, Zajac JM (1993) Quantitative autoradiographic mapping of delta-opioid receptors in the rat central nervous system using $\left[{ }^{125} \mathrm{I}\right]\left[\mathrm{D} . \mathrm{Ala}^{2}\right]$ deltorphin-I. Synapse 13:231-240.

Hiller JM, Zhang Y, Bing G, Gioannini TL, Stone EA, Simon EJ (1994) Immunohistochemical localization of mu-opioid receptors in rat brain using antibodies generated against a peptide sequence present in a purified mu-opioid binding protein. Neuroscience 62:829-841.

Hyytia P, Ingman K, Soini SL, Laitinen JT, Korpi ER (1999) Effects of continuous opioid receptor blockade on alcohol intake and up-regulation of opioid receptor subtype signalling in a genetic model of high alcohol drinking. Naunyn Schmiedebergs Arch Pharmacol 360:391-401.

Ji RR, Zhang Q, Law PY, Low HH, Elde R, Hokfelt T (1995) Expression of mu-, delta-, and kappa-opioid receptor-like immunoreactivities in rat dorsal root ganglia after carrageenan-induced inflammation. J Neurosci 15:8156-8166

Kieffer BL, Befort K, Gaveriaux-Ruff C, Hirth CG (1992) The delta-opioid receptor: isolation of a cDNA by expression cloning and pharmacological characterization. Proc Natl Acad Sci USA 89:12048-12052.

Koltzenburg M, Wall PD, McMahon SB (1999) Does the right side know what the left is doing? Trends Neurosci 22:122-127.

Kreek MJ (1996) Opioid receptors: some perspectives from early studies of their role in normal physiology, stress responsivity, and in specific addictive diseases. Neurochem Res 21:1469-1488.

Lee M-C, Cahill CM, Vincent J-P, Beaudet A (2002) Internalization and trafficking of opioid receptor ligands in rat cortical neurons. Synapse 43:102-111.

Maekawa K, Minami M, Yabuuchi K, Toya T, Katao Y, Hosoi Y, Onogi T, Satoh M (1994) In situ hybridization study of mu- and kappa-opioid receptor mRNAs in the rat spinal cord and dorsal root ganglia. Neurosci Lett 168:97-100.

Maekawa K, Minami M, Masuda T, Satoh M (1996) Expression of mu- and kappa-, but not delta-, opioid receptor mRNAs is enhanced in the spinal dorsal horn of the arthritic rats. Pain 64:365-371.

Mailly P, Gastard M, Cupo A (1999) Subcellular distribution of delta-opioid receptors in the rat spinal cord: an approach using a three-dimensional reconstruction of confocal series of immunolabelled neurons. J Neurosci Methods 87:17-24.
Mansour A, Fox CA, Burke S, Meng F, Thompson RC, Akil H, Watson SJ (1994a) Mu, delta, and kappa opioid receptor mRNA expression in the rat CNS: an in situ hybridization study. J Comp Neurol 350:412-438.

Mansour A, Fox CA, Thompson RC, Akil H, Watson SJ (1994b) mu-opioid receptor mRNA expression in the rat CNS: comparison to mu-receptor binding. Brain Res 643:245-265.

Meng F, Xie GX, Thompson RC, Mansour A, Goldstein A, Watson SJ, Akil H (1993) Cloning and pharmacological characterization of a rat kappa opioid receptor. Proc Natl Acad Sci USA 90:9954-9958.

Mennicken F, Zhang J, Hoffert C, Ahmad S, Beaudet A, O’Donnell D (2003) Phylogenetic changes in the expression of delta opioid receptors in spinal cord and dorsal root ganglia. J Comp Neurol 465:349-360.

Minami M, Maekawa K, Yabuuchi K, Satoh M (1995) Double in situ hybridization study on coexistence of mu-, delta- and kappa-opioid receptor mRNAs with preprotachykinin A mRNA in the rat dorsal root ganglia. Mol Brain Res 30:203-210.

Morinville A, Cahill CM, Esdaile MJ, Aibak H, Collier B, Kieffer BL, Beaudet A (2003) Regulation of delta opioid receptor trafficking through muopioid receptor stimulation: evidence from mu-opioid receptor knockout mice. J Neurosci 23:4888-4898.

Nguyen HM, Cahill CM, McPherson PS, Beaudet A (2002) Receptormediated internalization of $\left[{ }^{3} \mathrm{H}\right]$-neurotensin in synaptosomal preparations from rat neostriatum. Neuropharmacology 42:1089-1098.

Paxinos G, Watson C (1986) The rat brain in stereotaxic coordinates, Ed 2. London: Academic.

Petaja-Repo UE, Hogue M, Bhalla S, Laperriere A, Morello JP, Bouvier M (2002) Ligands act as pharmacological chaperones and increase the efficiency of delta opioid receptor maturation. EMBO J 21:1628-1637.

Pierce KL, Lefkowitz RJ (2001) Classical and new roles of beta-arrestins in the regulation of G-protein-coupled receptors. Nat Rev Neurosci 2:727-733.

Plobeck N, Delorme D, Wei ZY, Yang H, Zhou F, Schwarz P, Gawell L, Gagnon H, Pelcman B, Schmidt R, Yue SY, Walpole C, Brown W, Zhou E, Labarre M, Payza K, St-Onge S, Kamassah A, Morin PE, Projean D, Ducharme J, Roberts E (2000) New diarylmethylpiperazines as potent and selective nonpeptidic delta opioid receptor agonists with increased in vitro metabolic stability. J Med Chem 43:3878-3894.

Robertson B, Schulte G, Elde R, Grant G (1999) Effects of sciatic nerve injuries on delta-opioid receptor and substance $\mathrm{P}$ immunoreactivities in the superficial dorsal horn of the rat. Eur J Pain 3:115-129.

Sim LJ, Selley DE, Childers SR (1997) Autoradiographic visualization in brain of receptor-G protein coupling using $\left[{ }^{35} \mathrm{~S}\right] \mathrm{GTP}$ gamma $\mathrm{S}$ binding. Methods Mol Biol 83:117-132.

Stevens CW, Seybold VS (1995) Changes of opioid binding density in the rat spinal cord following unilateral dorsal rhizotomy. Brain Res 687:53-62.

Stevens CW, Lacey CB, Miller KE, Elde RP, Seybold VS (1991) Biochemical characterization and regional quantification of $\mathrm{mu}$, delta and kappa opioid binding sites in rat spinal cord. Brain Res 550:77-85.

Thompson RC, Mansour A, Akil H, Watson SJ (1993) Cloning and pharmacological characterization of a rat mu opioid receptor. Neuron 11:903-913.

Wang H, Wessendorf MW (2001) Equal proportions of small and large DRG neurons express opioid receptor mRNAs. J Comp Neurol 429:590-600.

Willis WD, Coggeshall RE (1991) Sensory mechanisms of the spinal cord, Ed 2. New York: Plenum.

Yasuda K, Raynor K, Kong H, Breder CD, Takeda J, Reisine T, Bell GI (1993) Cloning and functional comparison of kappa and delta opioid receptors from mouse brain. Proc Natl Acad Sci USA 90:6736-6740.

Zajac JM, Lombard MC, Peschanski M, Besson JM, Roques BP (1989) Autoradiographic study of $\mathrm{mu}$ and delta opioid binding sites and neutral endopeptidase-24.11 in rat after dorsal root rhizotomy. Brain Res 477:400-403.

Zhang X, Bao L, Arvidsson U, Elde R, Hokfelt T (1998) Localization and regulation of the delta-opioid receptor in dorsal root ganglia and spinal cord of the rat and monkey: evidence for association with the membrane of large dense-core vesicles. Neuroscience 82:1225-1242. 